\title{
Europæerne, EU og Acehs fredsproces
}

\section{Timo Kivimäki}

\section{EU's indflydelse på fredsprocessen i Aceh viser nødvendigheden af at forlade sig på europæerne snarere end kun at opfatte EU's institutioner som motoren for europæiske initiativer}

Aceh på Indonesiens nordvestspids har været et område i vedvarende konflikt siden 1976. Allerede i 1800tallet gav ønsket om uafhængighed sig udtryk i voldelig modstand imod den hollandske kolonimagt - og så såre hollænderne havde trukket sig ud - imod den nye centralregering $\mathrm{i}$ Jakarta i 1950'erne.

Konflikter så langvarige som Acehs er ofte meget vanskelige at løse, og i Acehs tilfælde har tsunamiens omfattende humanitære katastrofe siden vanskeliggjort fredsprocessen yderligere: Ud over at skulle søge en løsning på den politiske styreforms problemer er Aceh nu også nødsaget til konstant at bruge sine myndighedsstrukturer på at yde humanitær hjælp og genopbygge regionen. Ikke desto mindre har en forhandlingsproces været i gang siden 1999, og fra 2005 også en egentlig freds- proces, som i august samme år under ledelse Finlands tidligere præsident, Martti Ahtisaari, endte med underskrivelsen af et forståelsesmemonrandum om fred i Aceh.

Den Europæiske Unions komplicerede bureaukrati har i reglen været for klodset til at kunne bidrage til at løse konflikter, for slet ikke at tale om at løse langvarige konflikter i humanitære katastrofeområde. Ikke desto mindre var EU's involvering i Aceh ganske intensiv, og europæernes rolle blev da også afgørende for, at det lykkedes at få en fredsaftale i stand. Af denne grund forsøger mange asiatiske og europæiske sikkerhedsspecialister nu at generalisere læren fra Acehs fredsproces med det mål at finde frem til måder, hvorpå Aceh-modellen kan genbruges i andre konflikter.

I denne artikel vil jeg analysere 
Aceh-fredsprocessen med henblik på at bidrage til en sådan videreførelse af Aceh-modellen ud fra et europæisk perspektiv. Hvordan skal Europa organisere sine bidrag til fred for at undgå de vanskeligheder, der knytter sig til indblanding i så ømtålelige spørgsmål som konflikter? Og hvordan skal EU's usmidige bureaukrati blive i stand til at rykke tilstrækkeligt hurtigt til, at det kan blive en relevant medspiller i et fredsdiplomatis veje og vildveje?

For at finde svar på disse spørgsmål kunne det se ud til at vi må gå tilbage til den europæiske integrations neofunktionalistiske grundlæggelsesideologi: Vi må forstå EU som et projekt for borgerne snarere end som et projekt for institutioner. Institutionerne får først sekundært en rolle at spille og da kun til støtte for initiativer fra europæerne. Den Europæiske Union ser ud til kun at kunne blive til nytte, hvis dens institutioner mobiliserer sine europæiske aktiver i stedet for selv at søge at monopolisere initiativet.

\section{Genève-processen}

Det europæiske engagement i Aceh begyndte allerede, da præsident Ahtisaari i november 1999 blev introduceret for ledelsen af en af fraktionerne i separatistbevægelsen Frit Aceh (GAM). Med Ahtisaari som mægler var der allerede dengang et vist håb om dialog. Forhandlingerne blev imidlertid flyttet til Genève, hvor Henry Dunant Centeret overtog mæglerrollen i foråret 2000. Det er sandsynligt, at Henry Dunant Centeret blev foretrukket ud fra den betragtning, at forhandlinger med deltagelse af en officiel repræsentant for et suverænt land, Finland, ville signalere anerkendelse af GAM som repræsentant for en suveræn stat. Dette ville selvsagt have været uacceptabelt for Indonesien.

Den oprindelige strategi var at overtale GAM's ledelse til at forhandle ved først at indlede samtaler med en mere forhandlingsorienteret udbrydergruppe. Det skabte bekymring i det egentlige GAM om, hvad deres stilling var: Det så nemlig ud til, at en internationalt synlig forhandlingsproces risikerede at få en udbrydergruppe til at fremstå som det egentlige GAM. For at afværge dette blev GAM villig til at forhandle, og mægleren accepterede de deraf følgende justeringer i GAM-panelet for at sikre sig, at den ledelse, som havde den reelle kapacitet til at kommandere med tropperne i området, også blev involveret.

Forhandlingerne under Henry Dunant Centerets auspicier præsterede at opnå en våbenhvile og den optimisme, som dialogen gav anledning til, fik også til følge, at tabstallene blev betragteligt reduceret. Således reddede processen trods alt menneskeliv, selv om den endte i fiasko. Problemet med Genève-processen var, at den ikke udrettede meget i forhold til fastsætte de politiske be- 
tingelser for en varig fred. Betingelserne i Våbenhvileaftalen af december 2002 henviste ganske vist til politiske principper, men disse var så tvetydigt formulerede, at det ikke var muligt at overvåge deres implementering. I sidste ende resulterede uenigheder om implementeringen i et sammenbrud for fredsprocessen, og i maj 2003 proklamerede Indonesiens regering krigsretstilstand i Aceh og lod det lokale acehnesiske forhandlingshold fængsle.

Trods fiaskoen var der mange ting at lære af første fase af Aceh-fredsprocessen, som kunne bruges i den næste proces. For det første var alle de forhandlere, der deltog på højeste niveau de samme i både Genèveog Helsinkiprocesserne. De personlige kontakter mellem disse ledere var en første psykologisk forhåndsbetingelse for at få succes i Aceh. Ydermere kunne mange af de politiske ideer, der blev udviklet og fandt deres første vage definitioner i Genève, senere tjene som det oplagte udgangspunkt for de genoptagne politiske forhandlinger.

Men Genève-aftalerne blev også et lærestykke om Europas potentielle rolle i Aceh-fredsprocessen. For det første gjorde fængslingen af GAM's forhandlerpanel det uafviseligt klart, at en international rolle ville være nødvendig for at kunne løfte en næste runde. Det ville være umuligt for GAM at forhandle, hvis der ikke kunne findes et neutralt mødested. For det andet havde Genève-pro- cessen vist noget om værdien af uofficielle aktiviteter. Hvis allerede Finlands præsident ville være en for officiel mægler, måtte en officiel rolle for Den Europæiske Union da anses for fuldkommen utænkelig i forhandlinger mellem en stat og en oprørsbevægelse.

For det tredje viste denne proces også den store betydning af personlige, uformelle kontakter. Fleksibel manøvrering for personlige kontakter var fra dialogens begyndelse en mulighed for europæere, men ikke for en rigid europæisk politisk institution. Den oprindelige GAM-udbrydergruppe blev opsøgt af en forsker (denne artikels forfatter), som både havde interviewet udbrydergruppen og den egentlige GAM-ledelse til brug for sin forskning. Hans rådgivning havde også bragt ham i kontakt med præsident Ahtisaari.

Den forskningsrelaterede kontakt bredte sig til politik og senere til toppolitik. Som følge af separatismeog oprørsbevægelsers prekære stilling $\mathrm{i}$ internationalt diplomati ville det ikke have været let for politiske repræsentanter at fastholde en kontakt til oprørsgrupper. Følgelig var der god brug for interaktion imellem officielle og uofficielle, formelle og uformelle kontakter.

\section{Før Helsinki}

Helsinki-forhandlingsrunden var under forberedelse i omtrent et år. Igen blev de første kontakter skabt 
af individer i deres uofficielle egenskaber. Denne gang forplantede den politiske kontakt sig fra en professionel forbindelse mellem to forretningsmænd og læger. På indonesisk side var chefarkitekten den indonesiske viceminister, Farid Husain, der som uddannet læge kendte den finske læge og forretningsmand Juha Christensen. Sidstnævnte var blevet opmuntret til et omfattende forretningsprojekt i Aceh.

Disse to blev chefarkitekterne og "matchmakerne" i den fredsoperation, der kom til at involvere præsident Ahtisaari (I Finland er præsidenttitlen livsvarig; Ahtisaaris embedsperiode ophørte i 2001). Farid Husain havde deltaget i dialogprocessen under daværende minister og senere vicepræsident Jusuf Kalla på Molukkerne og i Poso på Sulawesi. Juha Christensen kendte på sin side både GAM's ledelse og igennem forskeren, som var involveret fra begyndelsen af Genèveprocessen, også præsident Ahtisaari.

Ret hurtigt lykkedes det for dem at overtale et tilstrækkeligt stort antal ligesindede indonesiske regeringsembedsmænd til at støtte en dialog med GAM. At overtale GAM viste sig som en mere vanskelig opgave. Farid Husain gjorde et forgæves forsøg på at få GAM's ledelse i tale i Sverige i foråret 2004. Kun Juha Christensen blev budt inden for i GAM's kontor (som også er GAM-lederen, Hasan di Tiros private hjem), mens Farid Husain pænt måtte vente udenfor. Således blev Christensen nødt til fysisk at pendle frem og tilbage mellem de stridende parter ind og ud af GAM-lederens hjem.

I sommeren 2004 må der være gjort adskillige bestræbelser for at overtale GAM's ledelse til dialog, men $i$ al fald nogle af dem involverede atter individuelle europæere med sådanne forbindelser til GAM, der ikke havde relation til politiske anliggender. Det ser ud til, at argumenter, der påberåbte sig den nu fratrådte præsident Ahtisaaris personlige egenskaber og position, blev de afgørende og fik GAM til at forandre sin position. En tidligere præsident med højt profilerede mænglingserfaringer appellerede til lederne af det acehnesiske oprør.

I kraft af Ahtisaaris internationale prestige og autoritet følte Malik Mahmood, GAM's chefforhandler, at han ville være tilstrækkelig magtfuld til at garantere en fair procedure, således at den indonesiske regerings militære overlegenhed ikke risikerede at blive udnyttet i forhandlingerne på unfair vis. Samtidig var det de stik modsatte egenskaber hos præsident Ahtisaari, som appellerede til Indonesiens regering. Skønt Ahtisaaris prestige naturligvis også var vigtig for den indonesiske side, var det faktum, at han ikke længere fungerede som præsident til hjælp for indoneserne, fordi hans status ikke længere rakte til at placere forhandlingerne i et regi, der vil- 
le signalere en de facto anerkendelse af Aceh som stat.

Ahtisaaris uofficielle position sikrede også, at forhandlingsprocessen kunne forblive under de forhandlende parters fulde kontrol.

For Indonesien ville det have været umuligt at acceptere en forhandlingsproces under et eller andet officielt arrangement, eftersom Indonesien opfattede, Aceh som et indre anliggende, hvorfor ingen officiel organisation kunne tillades at få nogen kontrol over processen. Endelig, efter præsidentvalget i efteråret 2004, der bragte Susilo Bambang Yudhuyono til magten med Jusuf Kalla som vicepræsident var begge parter rede til at forhandle.

Den måde, hvorpå en politisk vilje til atter at forhandle blev genskabt, understreger den rolle uformelle handlinger kan spille. Processen omfattede stadig ikke EU i nogen udstrækning, skønt den europæiske rolle var afgørende. Den eneste mulige involvering af EU's institutioner var brugen af et EU-finaniseret netværk af specalister i Aceh-konflikten for at fremme kontakter og ideer, der var relateret til de holdninger, der var gældende i Aceh.

Senere blev dette netværk formelt knyttet til mæglerpanelets aktiviteter. EU's finansiering fandt sted inden for rammerne af det kommissionsstyrede Asia Link-program, og målsætningerne for det specifikke projekt i Indonesian Conflict Studies Network blev defineret som "en aka- demisk opbygning af indfødtes konfliktløsningskompetencer i indonesiske konfliktområder". I dette regi fandt et uafhængigt og uofficielt universitetssamarbejde sted inden for de forhåndsaftalte politiske regler, mens initiativerne for at knytte denne aktivitet til en forberedende forhandlingsproces, i den udstrækning dette kunne lade sig gøre inden for projektets rammer, blev taget af netværkets individuelle medlemmer selv.

Denne model viste sig at rumme opskriften på EU's første rolle i den forhandlingsproces, der startede i januar 2005.

\section{Helsinki-forhandlingerne}

Ved begyndelsen af Helsinki-forhandlingerne var finansieringen af dialogen endnu ikke sikret. I løbet af den første måned var det endnu usikkert, om nogen ville finansiere rejserne og arbejdet med dialogen, og de mennesker, der deltog, måtte selv afholde omkostningerne til deres indsats. Skønt det i dag kan forekomme at være et trivielt spørgsmål, så blev det på dette tidspunkt ikke anset for trivielt, da der på ingen måde var garanti for at denne proces ville udmunde i nogen som helst resultater. Faktisk kunne hele processen være stoppet som følge af manglende finansiering.

Det var på dette tidspunkt at EU meldte sig med fuld styrke og brugte Kommissionens mandat til at 
iværksatte en "Rapid Reaction-mekanisme" (RRM). Igen var de politiske rammer for programmet blevet besluttet inden for en lang og usmidig politisk proces inden for EU, hvorimod anvendelsen af "Rapid Reaction-mekanismen" som ramme inden for dens forhåndsfastsatte politiske mandat kunne realiseres relativt hurtigt. Denne mekanisme gav forhandlingsprocessen seks måneders pusterum til at fuldføre forhandlingsprocessen.

Skønt præsident Ahtisaari selvsagt informerede de relevante embedsmænd fra Kommissionen og Rådet om forhandlingernes forløb, havde EU ikke nogen reel rolle i ledelsen af forhandlingerne. Det faktum at finansieringen kom fra Kommissionen, sikrede også processens uafhængighed. Ydermere blev forhandlingerne gennemført ud fra princippet om, at "intet er accepteret, før alt er accepteret". Dette hjalp til at sikre fuld kontrol over processen med de stridende parter. Det, som motiverede Ahtisaari til at holde EU's embedsmænd orienteret om processen, var ikke så meget det faktum, at EU stod for finansieringen, som at han hele vejen igennem forhandlingens forløb forudså den mere officielle rolle, der ville tilkomme EU i den fase, der skulle følge efter forhandlingerne.

Han følte det naturligt, EU skulle holdes underrettet, således at det bedre kunne forberede sig selv på den rolle, det kunne spille, når en aftale var på plads.

Forhandlingsprocessen viste, at når aftalerne først var implementeret, ville det blive nødvendigt med større politisk magt i overvågningsprocessen end i den uformelle mæglingsproces. I begyndelsen af forhandlingerne var der interessekonflikter imellem centralregeringen og den regionale militære ledelse. I 18 måneder havde Aceh været en provins, der var lukket af for enhver gennemsigtighed, fordi indonesisk militær anså dette for bydende nødvendigt for sin oprørsbekæmpelse. Resultatet var, at området blev et paradis for alle slags illegale aktiviteter fra det lokale indonesiske militærs side. I fraværet af en stærk international overvågning ville den indonesiske regering ikke blive $\mathrm{i}$ stand til at inddæmme presset fra hæren og implementere en fredsaftale.

Heldigvis for fredsprocessen havde den indonesiske regering det internationale samfund på sin side $\mathrm{i}$ kraft af den omstændighed, at Aceh efter tsunamien blev fyldt med internationale repræsentanter for hjælpe- og donororganisationer. På grund af disses tilstedeværelse blev det muligt for begge de stridende parter at kontrollere deres unge brushoveder og krigeriske elementer, som ikke kunne bifalde dialogen. Bl.a. protesterede flere enheder og officerer i Indonesiens militær imod, at der skulle forhandles med "terrorister". 
Ifølge hærens stabschef, general Ryamizard Ryacudu, kunne konflikten kun bringes til ophør med GAM's betingelsesløse overgivelse. Hvor den øverstbefalende for Indonesiens Væbnede Styrker, den indonesiske militærchef Endriartono Sutarto, udviste større loyalitet over for den politiske administration, demonstrerede mange tropper i Aceh deres støtte til stabschefen ved at optrappe de militære operationer i en bestræbelse på at sabotere fredsprocessen. Den internationale tilstedeværelse var derfor allerede under fredssamtalerne vigtig for forhandlerne i de andre forhandlinger, de sideløbende måtte føre for at få deres egne folk til at makke ret.

\section{EU som overvåger af fredsaftalen}

Efter at forhandlingerne lykkedes, og fredsaftalen var kommet i stand, var tiden inde til at bevæge sig fra det uofficielle til det officielle, fra den forsigtige, ikke-truende involvering til den mere magtfulde og strukturelle involvering.

For at sikre over for begge sider, at deres respektive modpart implementerede deres del af aftalen i god tro, blev EU kaldt på banen for at deltage i en formel rolle. Eftersom begge parter til en vis grad var afhængig af europæisk good will og EU's markeder, kunne EU bruge sin strukturelle magt til at påvirke de stridende parters nyttekalkuler, således at de bedre kunne se fordelene i at overholde aftalen. Til dette formål var uofficielle, frivillige aktiviteter fra enkeltindividers side ikke længere tilstrækkeligt. En stærkere, officiel aktør var nødvendig for at gøre aftalebrud omkostningstung og aftaleoverholdelse lønsom. Dette var også nødvendigt for at øge parternes tillid til, at deres respektive modpart ville overholde aftalen.

En mekanisme blev skabt, hvor EU sammen med nogle sydøstasiatiske lande dannede en overvågningsmission, der fik et exceptionelt vidtrækkende mandat og magt til at mægle i tilfælde af stridigheder mellem GAM og Indonesien om den rette tolkning af fredsaftalen. Mandatet blev legitimeret og gjort formelt bindende ved en officiel aftale mellem EU og Indonesiens regering, og mellem GAM og EU.

På dette stadium, hvor tredjepartsinvolveringen var mere strukturel, og større forhandlermagt var påkrævet for at hindre overtrædelser af aftalen, var det nødvendigt, at EU's råd fandt frem til en formel, der kunne gøre det muligt at etablere EU's del af overvågningsmissionen.

Den sidste fase af Acehs fredsproces har klart vist, at EU's instrumenter kan være af vital indflydelse for en fredsproces, selv når EU tillader civilsamfundsaktører at tage initiativet. Alt dette stemmer fint overens med neofunktionalismens ideer, hvor freds- og integrationspolitik igangsættes af borgerne, men hvor håndhævelsen af de folkelige nor- 
mer kræver formelle processer og magtfuld officiel involvering.

\section{Konklusioner}

For at få succes i sine bestræbelser for at fremme fred, er EU nødt til at forlade sig på europæerne snarere end kun at opfatte EU's institutioner som motoren for europæiske initiativer.

Acehs fredsproces beviser behovet for at bruge forskellige typer instrumenter til at hjælpe en fredsproces på gled. Den viser behovet for at kunne bevæge sig imellem de officielle og de uofficielle, mellem de formelle og de uformelle, mellem de magtfulde og de fintfølende, og mellem de rigide og de fleksible interventioner. Men samtidig bliver der i EU's udvikling kun rettet seriøs opmærksomhed imod at udvikle officielle mekanismer og forenet handling - ikke på at udvikle mekanismer, der kan fremme uofficielle aktioner eller på den kendsgerning, at europæerne bedst kan fremme freden i en stor mangfoldighed af roller.

Hvis Europa i sine bestræbelser for at fremme fred og sikkerhed sætter al sin lid og alle sine forhåbninger til fælles handling, fælles udenrigspolitik, og fælles sikkerheds- og forsvarspolitikker, vil det aldrig blive i stand til at kombinere de officielle med de uofficielle, de magtfulde med de fintfølende, og de rigide med de fleksible instru- menter. Fred og sikkerhed behøver ikke kun integration og enhed, men også individuelle innovationer $\mathrm{og}$ europæisk diversitet.

For at kunne efterligne Aceh-modellen må Europa besinde sig på sin neofuktionalistiske oprindelse og erkende, at den succesrige fredsopbygning i Europa var et produkt af spontane europæiske - snarere end institutionelle, officielle - initiativer, og at dens succes krævede samarbejde mellem EU's institutioner og dets befolkning.

Dette kunne også være en vej til at genvinde den europæiske tiltro til EU: Hvis EU ikke viser tiltro til europæerne, er det svært at forvente af europæerne, at de skal vise tiltro til EU. På et tidspunkt, da europæerne netop ser på EU's institutioner med betydelig mistillid, er det vigtigt, at EU udbreder det budskab, at EU's mekanismer til fremme af fred også er åbne for europæerne i stedet for at signalere det modsatte med sin bureaukratiske arrogance.

Europa kan kun mobilisere sit potentiale som fredsstøtte, hvis det forstår at værdsætte sin diversitet og samtidig støtter initiativer fra det europæiske civilsamfund med officielle EU-instrumenter.

Timo Kivimäki er seniorforsker ved NIAS - Nordisk Institut for Asienstudier (Oversat fra engelsk af Niels Ivar Larsen) 